ЕКОНОМІЧНА НАУКА, ОСНОВНІ ЕКОНОМІЧНІ КОНЦЕПЦІЇ, TЕОРІЯ

UDC 338.31

JEL Classification: E60

Nikileva N.A.

\title{
ECONOMIC POTENTIAL AND FINANCIAL GROWTH MECHANISM
}

\author{
Ukrainian State University of Chemical Technology, Dnipro, Ukraine
}

\begin{abstract}
The article presents an approach to the analysis of the economic potential, its structure and the problem of growth. It justifies the need to increase the influence of financial levers and incentives to strengthen and increase the economic potential. Identified the main problem aspects of the financing mechanism to increase economic potential. Economic potential is the subject of scientific research in modern economics. At the same time, how the analysis of publications on this issue shows, in this area of knowledge there are no uniform views on the factors, levers and incentives of increasing economic potential; the conceptual apparatus of the theory is diverse, many-sided and is in the process of searching for a single methodological basis for its formation; the practical absence of a clear understanding of the financial mechanism for its effective growth and use. Without a financial and material base it is impossible to achieve the accumulation of any values, especially when we talk about building up the national wealth - the economic potential of the country. An urgent task is to develop a reasonable program of action for the introduction of financial levers and incentives, which will provide the desired result.
\end{abstract}

Keywords: definition of potential, economic potential, fiscal policy, state support, financial leverage, profit, financial mechanism.

DOI: $10.32434 / 2415-3974-2018-8-2-7-10$

\section{Intriduction}

Today, the statement of Economic that the factors of production have a common property is perceived as an axiom: they are rare or are available in limited quantities. As a consequence, social production opportunities are also limited. Based on the existing potential output can be satisfied needs, it means spending a certain percentage of limited resourses, reduced saturation of remaining needs. Hence the necessity of choosing between production alternatives from the available options for combinations of resources, from the available economic potential [11].

The economic potential is the total capacity of national economies to produce goods and services, to innovate, to invest in order to satisfy the needs and reserves. The economic potential of a country is determined by its natural resources, means of production, labor, scientific and technical potential, accumulated national wealth [4].

Analysis of recent research and publications

Theoretical aspects of the analysis of the economic potential, its main components, problems of growth, the financial mechanism of its support, and the features of the Ukrainian formation and development are considered in the works of foreign and domestic economists, in particular, such as Volkova E.V., Romanov A.P., Serebrennikov G.G., Bezuglaya O.V., Gusakov V.G., Astrakhantseva I.A., Karapeychik I.N., Charykova M.K., Kirilina O.V. $[1,6]$ Especially, it is necessary to highlight the Ukrainian authors who have devoted their scientific work to the main problems of industrial policy, innovative transformations in the Ukrainian economics and on this basis to accelerate the growth rates of economic potential, financial aspects of its provision: Danilenko A.I., Zveryakov M.I., Amosha O.I, Solomatina L.I., Pilipenko O.V., Mazur V.L. A review of publications has illustrated the lack of unity of views on the structure of economic potential, the financial mechanism for achieving its growth, priority in financial leverages and incentives as elements of this mechanism $[10,13]$.

\section{Statement of the main material}

The concept of «economic potential» is a multifaceted, to some extent collective. In its

(C) Nikileva N.A., 2018 
definition, the keyword is «totality». In economic theory, the potential (from the Latin «potentia» force) is described as a set of available resources, opportunities in any field, cash reserves and sources in order to achieve a certain goal, realization of plans and objectives. According to the E.V. Volkova, A. Romanov, A. Denisov and other authors, potential - objectively existing system, consisting of several interconnected elements, subsystems, features, efficient use of which will achieve the goal of social and economic development [2,12].This system includes a variety of structure-forming units, many types of potentials: production resource, financial, management, marketing, market, information, labor, scientific, business, etc. All these species are united by the category of "economic potential".

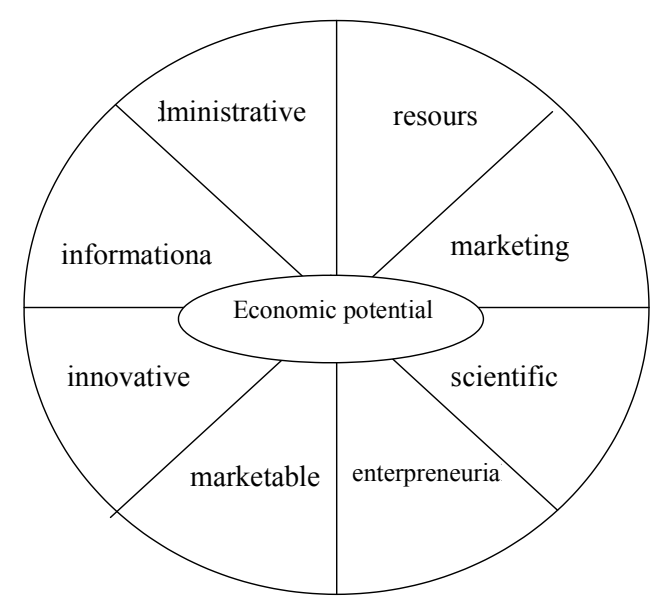

Fig. 1. Structure-forming units of economic potential

All listed segments of economic potential are inextricably connected and interact with each other. So resource potential can be considered as a set of available economic resources(production factors), that is raw materials, capital, labor, scientific, information, business and other resources, coordinated with each other in order to achieve the desired economic effect. It has been argued that the resource potential is the foundation for the creation and development of economic potential [5].

Approaches to analyzing economic potential at macro and micro levels are common.

The macro level, that is, in the scale of the national economy, is connected with the analysis of the economic potential as a systemic interaction of the production factors existing in the country at all levels of management and is associated with the policy of macroeconomic stabilization. His main subject is government.

At the microlevel - the enterprise level concept of economic potential outlined by a complex of objects, that belongs to this economic entity(property potential), and financial position and financial capabilities of the enterprise. Consequently, the totality of all the means of labor, stocks and reserves, professional skills of employees of the company, that allow to achieve the main goal of the functioning of any business structure - profit maximization - and form the economic potential of the company(enterprise) [9]

Theoretical aspects of the analysis of economic potential are based on unity, interconnection of it's structural elements: labor, raw materials, scientific, information resourses, ivestment goods and other., that contribute to the strengthening of productive economic opportunities, both now and in the future. Success is possible subject to the development and implementation of the existing financial mechanism, which is able to stimulate progress in the qualintative growth of economic potential.

A)Improvement of legislation aimed at supporting economic potential and creating financial levers and incentives for its provision.

B)Effective use of financial leverage and incentives cannot be imagined without state support.

In order to strengthen the incentive role of tax benefits in Ukraine, several steps have been taken to adjust the decisions on changing selected articles of the Ukrainian Tax code due to the need of reduction losing tax revenues to the budget,(income tax and VAT benefits). Active use of tax benefits can create the conditions for ensuring the growth of economic potential.

Creation of the National industrial development committee, whose main task is evaluation and consultation of the government on the technical reequipment of production; increasing the efficiency of state administration of the innovation environment. Consequently, the committee is called upon to provide conditions for the implementation of a hightech model of production in Ukraine.

At the enterprise level, capacity building sources are own funds that are formed from depreciation and profit.

One of the developed ways of increasing the economic potential is borrowed and attracted capital. We are talking about long-term and short-term loans and targeted financing.

Also such levers include financial support for the development of small and medium businesses; organization of monitoring projects for assessing the prospects of ongoing and innovative investment programs; the adoption of targeted programs to stimulate the growth of industrial production, technological re-equipment of perspective industries; subsidizing part of the cost of small business.

In order to increase economic potential, the government can activate an innovative investment mechanism transformed into industry; implement state innovation programs; form technology parks; to provide legal protection of the rights and interests of business entities; to stimulate commercial banks 


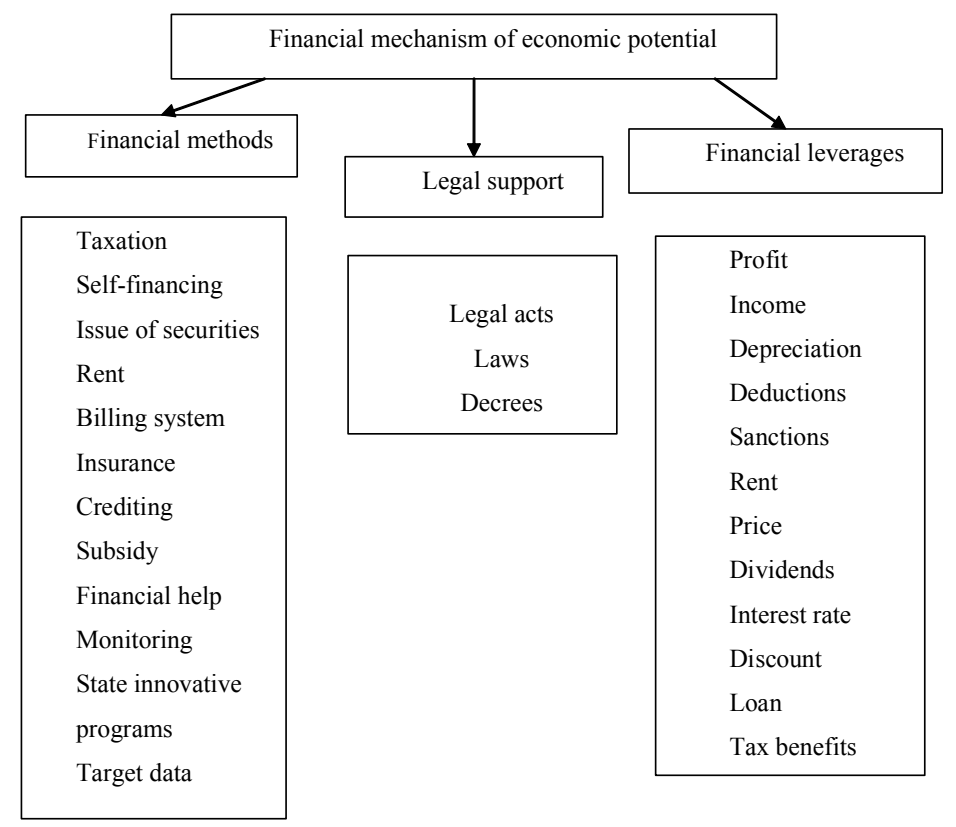

Fig. 2. Main parts of financial mechanism of economic potential

and parabanks that provide loans for projects that protect and fulfill economic potential.

In such a collective concept as «economic potential», as was shown above, there are many components, which complicates the selection of the elements of its financial mechanism; each segment has its own levers and incentives. Such financial levers as profit, income, depreciation, financial sanctions, interest rate, price, rent, dividends affect on the formation and strengthening of the investment potential. It is known that own funds of economic entities are formed from depreciation deductions and profits, but in Ukraine, due to low profitability of production, a large number of unprofitable enterprises, the amount of depreciation and weak government support for investment activity led to a deterioration in the ratio of investment to GDP. According to the data of the World Bank, the ratio of capital investments to Ukraine's GDP in 2016 was $13.7 \%$, in China $-43.3 \%$ [7].

A serious step towards ensuring an increase of economic potential on the part of the state is have to be introduction of scientific technological reequipment in industries capable in perspective to go into innovative investment development model. Incentive directions of this process are budjet lending; control of state financing of investment projects; strengthening of state science development regulation; increase in depreciation; loss reduction; preferential state assistance to business. Therefore, these steps are coming down to engaging all subsystems of financial mechanism as a method of influence on economic potential. The idea of creating the Ukrainian Development Bank should be supported with the aim of intensification its

\section{functioning [3]}

\section{Conclusions}

The effectiveness of the financial mechanism of the economic potential should be manifested in the innovation-investment model of its growth and modernization. In this regard, the state can activate innovations, stimulate innovative development of industries and enterprises on the basis of the state innovation management system. Such a system involves the support of priority areas of innovation; the formation and implementation of state, sectoral, regional programs; placement of state orders in the scientific and technological sphere, legal protection of the rights and interests of subjects of innovation activity; stimulation of commercial banks and parabanks providing loans for the implementation of innovative projects, preferential taxation, flexible depreciation policy. An effective mechanism to stimulate innovation and on this basis the growth of the economic potential in Ukraine is still not functioning, which has been repeatedly emphasized by domestic economic scientists [8], who offer to give priority to financial incentives, legal regulation, budget financing, crediting and financial support of enterprises and industries potentially subject to innovative re-equipment, modernization and, consequently, contribute to building the capacity of the domestic economy.

\section{REFERENCES}

1. Astrakhantseva, I.A. (2013) [Assessment of the financial potential of economic growth organization .] - Financial analytics, №15(153), 31-37 [in Ukrainian]. 
2. Campbell R. McConnell, Stanley L. Brue. (1992) [Economics. Principles, Problems and Policies. 1 Vol.11 ed.] «Respublika» 399, tabl., sch. - p.38 [in Ukrainian].

3. Danilenko, A.I. (2017) [The main problems of innovation restructuring and financial aspects of its provision in Ukraine Funds of Ukraine №5]. 7-23 [in Ukrainian].

4. Electronic dictionaries and encyclopedias. Access mode: http://dic.academic.ru.

5. Gusakov, V.G. (2008) [Economics and organization of agriculture in the conditions of market formation: scientific search, problems, solvings.] - Minsk: «Belarusian science» 43 [in Ukrainian].

6. Karapeychik, I.N. (2011) [The concept of potentials economics: the general concept - Efficient economy] №12.(electronic scientific publication) [in Ukrainian].

7. Official website of World Bank. Access mode: http:// www.worldbank.org.

8. Pylypenko, O.V (2016) [States control over the innovative activity in Ukraine: problems and perspectives - Ukrainian economics] №9, 31-43 [in Ukrainian].

9. Romanov, A.P., Serebrennikov, G.G., Bezuglaya, V.M., Kirilina, O.V., Charykova, M.K. (2012) [Management of the economic potential of the organization: study guide]- Tambov: «TTU», 88 [in Ukrainian].

10. Rumyantsev, A.M. (1980) [Economic encyclopedia. Political economy. Vol.4]: «Soviet Encyclopedia». 672p. [in Ukrainian].

11. Sidorovich, A. V. (ed.) (2001) [The course of economic theory. General principles of economic theory. Microeconomic. Macroeconomic. Basis of national economy: Study guide] Moscow: «Delo i Servis». 832 p. [in Ukrainian].

12. Volkova, E.V. [Economic potential: essence, classification and structure of the economic problem], №1(24), 24-32 [in Ukrainian].

13. Zveryakov, M.I. (2016) [Industrial politics and the mechanism of its realization -Ukrainian Economics] №6. 3-18 [in Ukrainian].

Received 20.10.2018

Reviewer: ass. prof. ass. Prof Chupryna N.M.

\section{МЕХАНІЗМ ЕКОНОМІЧНОГО ПОТЕНЦІАЛУ ТА ФІНАНСОВОГО ЗРОСТАННЯ}

\section{Нікілева Н.О.}

У статті наданий підхід до аналізу економічного потенціалу, його структури та проблем зростання. Обгрунтовується необхідність збільшення впливу фінансових важелів та стимулів на зміцнення та підвищення економічного потенціалу. Визначено основні проблемні аспекти механізму фінансування зростання економічного потенціалу. Економічний потенціал є предметом наукових досліджень в сучасній економіці. У той же час, як показує аналіз публікацій з цього питання, у цій галузі знань немає єдиних поглядів на фактори, важелі та стимули зростання економічного потенціалу; понятійний апарат иієї теорії різноманітний, багатогранний та знаходиться в процесі пошуку єдиної методологічної основи ї̈ формування; практичною відсутністю чіткого розуміння фінансового механізму їі ефективного зростання та використання. Без фінансово-матеріальної бази неможливо досягти накопичення будьяких иінностей, особливо коли ми говоримо про нарошування національного надбання - економічного потенціалу країни. Нагальним завданням є розробка обгрунтованої програми дій для запроваджсення фінансових важелів і стимулів, які забезпечать бажаний результат.

Ключові слова: визначення потенціалу, економічний потенціал, фіскальна політика, державна підтримка, фінансовий вплив, прибуток, фінансовий механізм.

\section{МЕХАНИЗМ ЭКОНОМИЧЕСКОГО ПОТЕНЦИАЛА И ФИНАНСОВОГО РОСТА}

\section{Никилева Н.А.}

В статье представлен подход к анализу экономического потенциала, его структуры и проблемы роста. Обосновывается необходимость усиления влияния финансовых рычагов и стимулов для укрепления и увеличения экономического потенииала. Определены основные проблемные аспекты механизма финансирования увеличения экономического потенциала. Экономический потенциал является предметом научных исследований в современной экономической науке. В то же время, как показывает анализ публикаций по этой проблематике, в данной области знаний отсутствуют единые представления на факторам, рычагом и стимулом роста экономического потенииала; понятийный аппарат теории разнообразен, многолик и находится в стадии поиска единой методологической основы его формирования; практическим отсутствием четкого представления о финансовом механизме его эффективного роста и использования. Без финансовой и материальной базы невозможнн добиться накопления каких-либо иенностей, а тем более когда речь идет о наращивании общенационального достояния - экономического потенциала страны. Актуальной становится задача разработки обоснованной программы действий по внедрению финансовых рычагов и стимулов, которая обеспечит желаемый результат.

Ключевые слова: определение потенциала, экономический потенциал, фискальная политика, государственная поддержка, финансовый рычаг, прибыль, механизм финансирования. 